\title{
Tap water as a source of indoor radon in houses
}

\author{
Iwona Klosok-Bazan ${ }^{1 *}$, Joanna Boguniewicz-Zablocka ${ }^{1}$, Vincenzo Naddeo ${ }^{2}$, \\ and Alina Domanowska ${ }^{3}$ \\ ${ }^{1}$ Opole University of Technology, Mikolajczyka 5, Opole, Poland \\ ${ }^{2}$ Department of Civil Engineering, University of Salerno, Fisciano, Italy \\ ${ }^{3}$ Silesian University of Technology, Akademicka 2A, Gliwice, Poland
}

\begin{abstract}
Outdoors, radon is quickly diluted to very low, not problematic concentrations but indoors, it can concentrate significantly. Places that are particularly exposed to an increased radon concentration from water sources are places where water is dispersed, e.g. bathrooms or areas in water treatment facilities. The aim of the paper is to present the calculation of radon escaping from water into the indoor area at home on the example of Mokre village. Mokre is supplied with water from an underground source containing radon $222 \mathrm{Rn}$ in concentration of about $200 \mathrm{~Bq} / \mathrm{L}$. The obtained data has been compared with WHO recommendation (WHO, 2009) and literature review. Considering that $300 \mathrm{~Bq} \cdot \mathrm{m}^{-3}$ are equivalent to $10 \mathrm{mSv}$ per year, which is equal to receiving approximately an annual full chest CT (computed tomography), the risk resulting from the emission of radon from tap water in Mokre has been assessed to be insignificant.
\end{abstract}

\section{Introduction}

Radon is a naturally occurring radioactive gas which may be found in indoor environments of buildings. The main source of radon in buildings is the ground underneath the building. But there are also other sources of this gas, such as construction materials, domestic water and gas supplies [1-3]. Outdoors, radon is quickly diluted to very low, not problematic concentrations for human health but indoors, it can concentrate significantly. Determining the indoor source magnitude requires knowledge of the generation of radon in source, its movement by diffusion and convection, and the means of its entry into buildings. The concept of radon potential can be used as a basis for estimating indoor radon concentrations and equivalent dose of ionizing radiation. However, it is not possible to accurately predict radon concentrations in individual houses because of the highly variable nature of factors. Comparing radon entering home through water to radon entering home through soil, the one from soil usually constitutes considerably higher risk. Radon is dissolved in groundwater and can be transported from the source, with water, into the building. Indoors, when water is exposed to air, radon is released. Showers and sprays are a prime release method and the greater the water usage, the greater the potential radon problem [3-7].

\footnotetext{
* Corresponding author: i.klosok-bazan@po.opole.pl
} 
Additionally, research has shown that risk of lung cancer from breathing radon in with air is much larger than risk of stomach cancer from consumption of water containing radon [811]. Therefore, the main risk connected with radon in water comes from radon released into the air when water is used for showering and other household purposes. Places that are particularly exposed to an increased radon concentration from water sources are places where water is dispersed, e.g. bathrooms and in other home water facility (e.g. jacuzzi, faucet aerator). However, one should be aware that where high radon concentrations are identified in indoor air, this is nearly always due to ingress of radon from the soil rather than degassing from the drinking-water supply. Therefore, indoor radon identification is more important than its identification from drinking water. In many countries of Europe, standards of reference levels for radon concentration in domestic environments have been introduced.

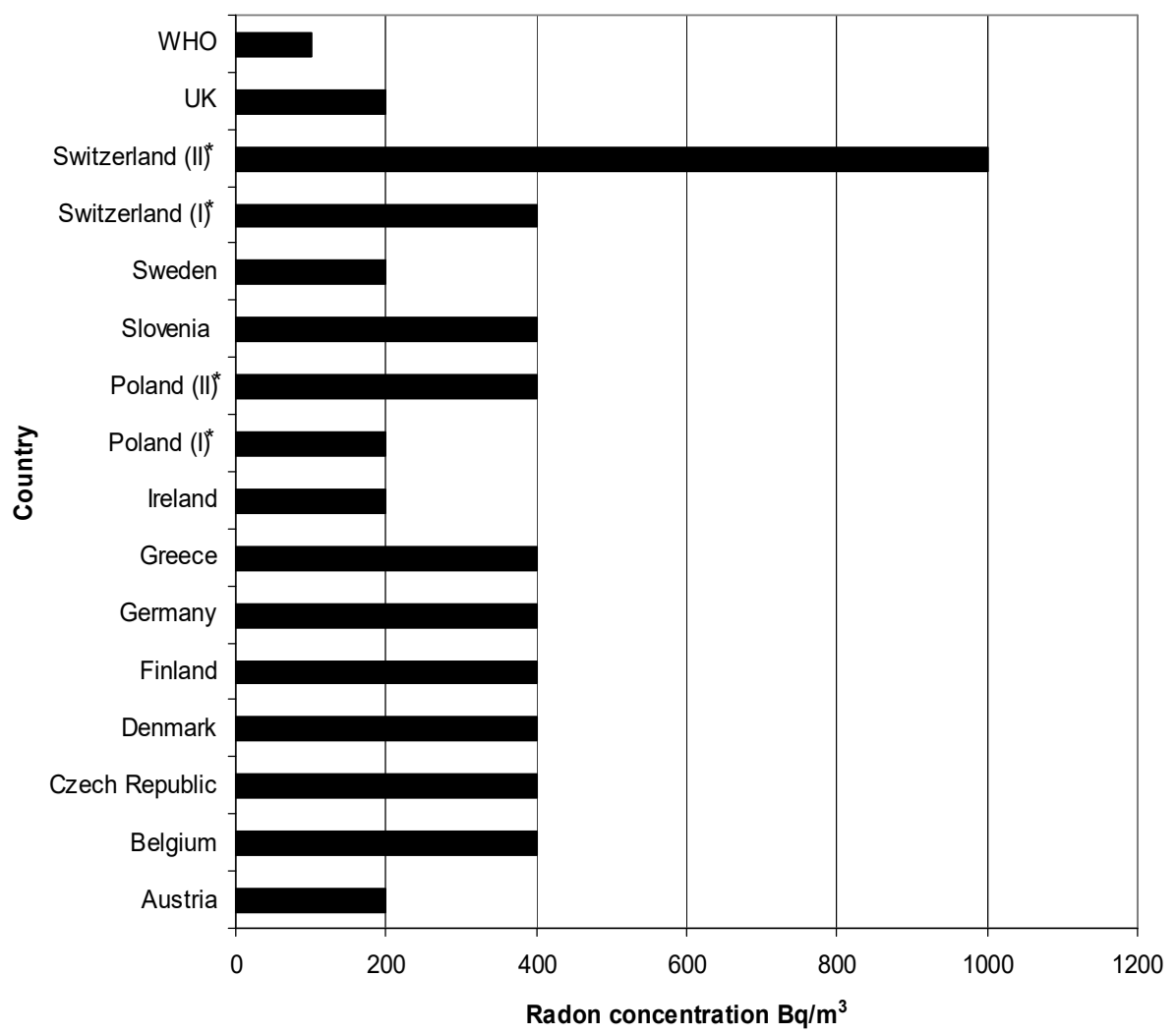

Fig. 1. Reference levels for radon gas in domestic environments [12]

*Poland (I) - in existing buildings put in the use before January 1, 1998;

Poland (II) - in existing buildings put in the use after January 1, 1998; Switzerland (I) - advisory reference level;

Switzerland (II) - compulsory reference level

Figure 1 presents that, in the majority of European countries, the permittable radon concentration in a room is equal to $400 \mathrm{~Bq} / \mathrm{m}^{3}$ and is $300 \%$ higher from the concentration recommended by the World Health Organisation (WHO) which suggests that radon concentration in a building should be decreased when its value exceeds $100 \mathrm{~Bq} / \mathrm{m}^{3}$. 
Currently, in Poland there are no unequivocal guidelines for acceptable levels of random concentrations in rooms, however, referring to the regulation of the President of the Polish National Atomic Energy Agency of 1995, it has been adopted that average annual concentration of radon-222 in rooms intended for continuous stay of people should not exceed: I) $400 \mathrm{~Bq} / \mathrm{m}^{3}$ in existing buildings put into use before 1 January 1988, II) 200 $\mathrm{Bq} / \mathrm{m}^{3}$ in buildings put into use after January 1988. In relation to standards of radon concentration in drinking water, WHO said that screening levels for radon in water should be set on the basis of the national reference level for radon in air and the distribution of radon in the national housing stock. The European Commission suggests a concentration reference level of $100 \mathrm{~Bq} / \mathrm{L}$ for radon in drinking water but if the activity is over 1,000 $\mathrm{Bq} / \mathrm{L}$ then remedial measures should be taken. Due to the implementation of EU directive [11] in the Polish law, 30 November 2017, such an obligation has been introduced. One of water intakes where radon concentration is higher from the concentration level recommended in the EU directive is Mokre intake in Głubczyce district. The permitted level of $100 \mathrm{~Bq} / 1$ [12] has been exceeded by almost $100 \%$.

\section{Description of Mokre water intake}

Mokre intake is located in the southern part of Opole Voivodeship in Głubczyce district. This area is characterized by a very specific geological structure. The land surface mainly consists of Lower Carboniferous clastic works shaped in the form of shales, sandstones and conglomerates, all of these works are characterized by increased radioactivity (Fig. 2).

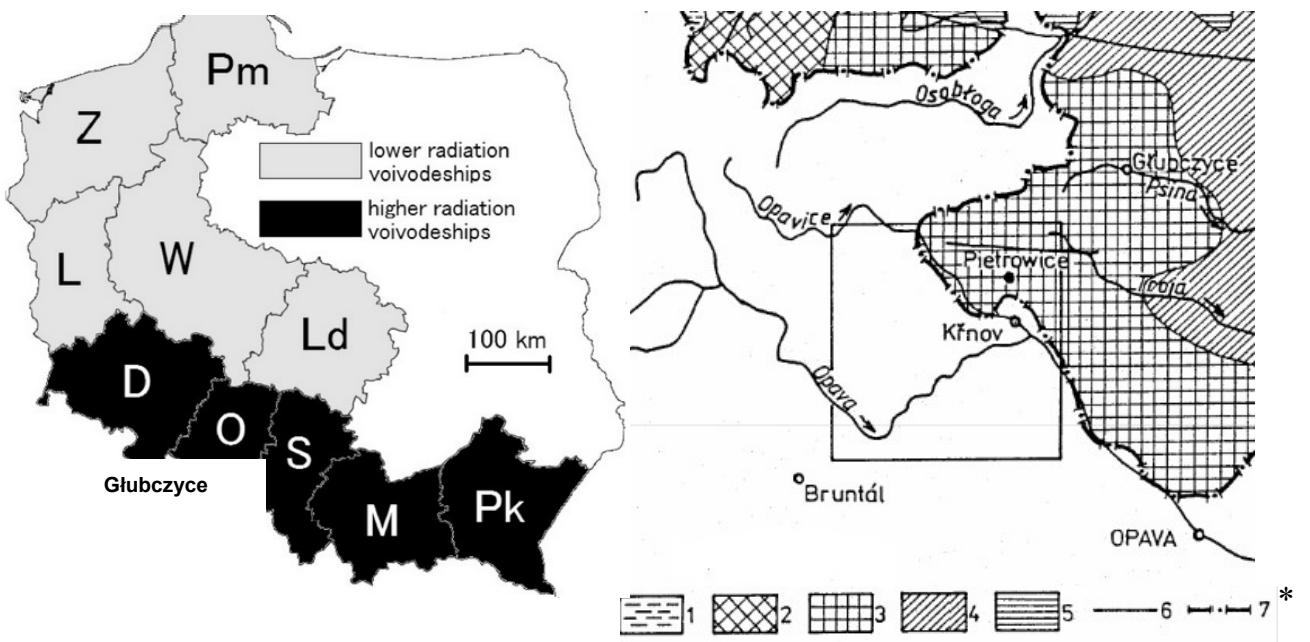

Fig. 2. Location, radiation level and geological sketch of the Glubczyce district [13, 14]

*Proterozoic and Cambrian-Silurian periods : 1 - gneisses and crystalline shales; Devon: 2 - slates, quartzites, phyllites, crystalline limestones, limestones, dolomites, marls, clay shales, greywackes and conglomerates; Carboniferous: 3 - conglomerates, greywackes, sandstones, mudstones and limestones; Cretaceous: Cenomanian and Turonian: 4 - limestones, writing chalk, marls, sandstones and bedrocks; Coniacian and Santonian: limestones, marls, bedrocks, writing chalk, local glauconite sands; 6 -stated dislocations, 7 -state border.

The intake used by Głubczyckie Wodociaggi i Kanalizacja sp. z o.o. operates under the permit no. OŚ.6341.34.2011 required by local Water Law Act issued by the district head of Głubczyce District. The water intake consists of one borewell which uses quaternary aquifers. Water is drawn from the depth of 7 metres and average well efficiency is 3.7 $\mathrm{m} 3 / \mathrm{h}$. Good water quality allows for its direct use, without the necessity to purify it. The 
results of analyses of the most important parameters of water quality in the well in Mokre are presented in Tab. 1. Therefore, water from the well could be directly fed to the storage tank with capacity of $40 \mathrm{~m}^{3}$ from where, through gravity flow, it was supplied to consumers. It is important to highlight the fact that the intake in Mokre is a very small intake, supplying water to barely over 200 residents and the cost of maintenance of intake and distribution system significantly exceeds revenues from sales of water.

Table 1. Water quality in Mokre intake [own work]

\begin{tabular}{|c|c|c|c|c|c|}
\hline \multirow{2}{*}{ Parameter } & \multirow{2}{*}{ Unit } & \multicolumn{3}{|c|}{ Results } & \multirow{2}{*}{$\begin{array}{c}\text { Determination } \\
\text { method }\end{array}$} \\
\hline & & $\min$ & maks & average & \\
\hline Reaction $(\mathrm{pH})$ & $\mathrm{pH}$ & 7,1 & 7,33 & 7,21 & PN-90/C-04540/01 \\
\hline Conductivity & $\mu \mathrm{S} / \mathrm{cm}$ & 473 & 488 & 480 & PN-EN 27888: 1999 \\
\hline Manganese (Mn) & $\mu \mathrm{g} / \mathrm{L}$ & 0.2 & 0.2 & 0.2 & $\begin{array}{l}\text { PN-EN ISO } \\
11885: 2009\end{array}$ \\
\hline Iron $(\mathrm{Fe})$ & $\mu \mathrm{g} / \mathrm{L}$ & 2 & 2 & 2 & $\begin{array}{l}\text { PN-EN ISO } \\
11885: 2009 \\
\end{array}$ \\
\hline Turbidity & NTU & 0.12 & 0.51 & 0.315 & PN-EN ISO 7027:2003 \\
\hline Color & $\mathrm{mg} \mathrm{Pt} / \mathrm{L}$ & $<5$ & $<5$ & $<5$ & PN-EN ISO 7887:2002 \\
\hline Odor & - & acceptable & acceptable & acceptable & organoleptic \\
\hline Taste & - & acceptable & acceptable & acceptable & organoleptic \\
\hline Ammonium $\left(\mathrm{NH}_{4}\right)$ & $\mathrm{mg} / \mathrm{L}$ & $<0.06$ & $<0.20$ & $<0.13$ & PN-C-04576-4: 1994 \\
\hline Nitrates $\left(\mathrm{NO}_{3}\right)$ & $\mathrm{mg} / \mathrm{L}$ & 29.8 & 29.8 & 39.4 & PN-C-04576-08:1982 \\
\hline Nitrites $\left(\mathrm{NO}_{2}\right)$ & $\mathrm{mg} / \mathrm{L}$ & $<0.01$ & $<0.01$ & $<0.01$ & PN-EN 26777:1999 \\
\hline Coliform bacteria & $\begin{array}{c}\mathrm{CFU} / 100 \\
\mathrm{ml}\end{array}$ & 0 & 0 & 0 & $\begin{array}{l}\text { PN-EN ISO 9308- } \\
\text { 1:2004+Ap1:2005 }\end{array}$ \\
\hline Escherichia coli & $\begin{array}{c}\text { CFU100 } \\
\mathrm{ml}\end{array}$ & 0 & 0 & 0 & $\begin{array}{l}\text { PN-EN ISO 9308- } \\
\text { 1:2004+Ap1:2005 }\end{array}$ \\
\hline Enterococci & $\begin{array}{c}\mathrm{CFU} / 100 \\
\mathrm{ml}\end{array}$ & 0 & 0 & 0 & $\begin{array}{l}\text { PN-EN ISO 7899- } \\
\text { 2:2004 }\end{array}$ \\
\hline
\end{tabular}

In line with amendment of the regulation of the Minister of Health on the quality of water intended for human consumption the owner of the intake was obliged to conduct the tests for content of radioactive substances in water intended for human consumption. The initial monitoring of radioactive substances containing the first test of level of concentration of radioactive substances in terms of occurrence of radioactive substances related to radon, radium isotopes: Ra-226, Ra-228 and tritium detected an increased concentration of radon in the intake in Mokre. The standard included in the Regulation of the Minister of Health established at the level of $100 \mathrm{~Bq} / \mathrm{L}$ was exceeded by $96 \%$, the concentration of radon at the level of $196 \pm 49 \mathrm{~Bq} / \mathrm{L}$ was also observed. The next analyses conducted in February 2018 confirmed the presence of radon in increased concentrations and the value of measurement result was $281 \pm 59 \mathrm{~Bq} / \mathrm{L}$. In line with the legal requirements, it is necessary to prepare the evaluation of water health risk and implement corrective measures aiming to limit the concentration of the aforementioned substance in water. According the above data, risk of lung cancer from breathing radon in with air is much larger than risk of stomach cancer 
from consumption of water containing radon. Therefore, while evaluating the health risk, most of all, it is necessary to consider the exposition to radon in air.

\section{Annual effective dose equivalent of radiation}

The calculations of annual effective dose equivalent of radiation (ADE) were based on assumptions presented by Pawula [15] who used the tests of the National Institute of Hygiene. According to the presented data, the exposure to radon in air, with radon concentration of $1 \mathrm{~Bq}$ per $1 \mathrm{~m}^{3}$ of air, during the time of 1 hour, results in intake of an effective dose equivalent (EDE) of ionizing radiation at the level of $9 \mathrm{nSv}$ by an adult person. The calculations were also based on the assumption of WHO that an average release of radon into the air is equal to ca. $10 \%$ and does not exceed $50 \%$ of total radon concentration in water. At the same time, according to Pawula [15], it was assumed that the equivalent equilibrium concentration (EEC) for radon inside buildings $F$ is 0.4 . The assumed estimated time of exposure to direct impact of radon: 30 minutes (average time spent in the bathroom while bathing). (2)

Substituting data in the formula (1) the radon emission in the bathroom was calculated

$$
E_{R n}=Q \times S_{R w} \times n
$$

where:

$E_{R n}-$ radon $\mathrm{Rn}-222$, emission from water [Bq];

$Q$-average use of water per 1 shower [L];

$n$ - coefficient of radon emission from water, 0.5 was adopted

$S_{R w}-$ radon $\mathrm{Rn}-222$ concentration $[\mathrm{Bq} / \mathrm{L}]$

$$
E_{R n}=100 \mathrm{~L} \times 196 \mathrm{~Bq} / \mathrm{L} \times 0.5=9800 \mathrm{~Bq}
$$

Referring the value calculated with the formula (2) to the average cubic volume of a bathroom, radon $\mathrm{Rn}-222$ concentration in the air of closed rooms - the "indoor" air, was calculated

$$
S_{R n}=E_{R n} / V=9800 B q / 15 m^{3}=653.33 B q m^{-3}
$$

where:

$V$ - cubic volume of non-ventilated bathroom ( $2 \times 3 \mathrm{~m}$ with height of $2.5 \mathrm{~m})\left[\mathrm{m}^{3}\right]$;

$E_{R n}$ - radon $\mathrm{Rn}-222$, emission from water [Bq]

Therefore, the annual effective dose equivalent of radiation for a person who takes a 10minute shower every day is (4 et 5)

$$
A D E=S_{R n} \times F \times E D E x N \times T
$$

where:

$A D E$ - annual effective dose equivalent $[\mathrm{mSv}]$;

$S_{R w}-$ radon $\mathrm{Rn}-222$ concentration $[\mathrm{Bq} / \mathrm{L}]$;

$F$ - equivalent equilibrium concentration (EEC) for radon inside buildings

$E D E$ - exposure to radon in air, with radon concentration of $1 \mathrm{~Bq}$ per $1 \mathrm{~m}^{3}$ of air, during the time of 1 hour, by an adult person

$N$ - namber of days in a year;

$T$ - exposition time per day [h].

$$
\begin{gathered}
A D E=\left(653 \mathrm{~Bq} \mathrm{~m} \mathrm{~m}^{-3} \cdot 0.4\right) \times\left(9 \times 10^{-9} \mathrm{~Sv} \cdot \mathrm{Bq}^{-1} \cdot \mathrm{m}^{3} \cdot \mathrm{h}^{-1}\right) \times(365 \cdot 0.5 \mathrm{~h}) \\
\underline{A D E=0,000429 \mathrm{~Sv}=0,429 \mathrm{mSv}}
\end{gathered}
$$


In case of efficient ventilation, this value will be even lower. Meanwhile, the estimates made by the National Atomic Energy Agency show that the annual effective dose equivalent of ionizing ration received by a statistical Polish citizen from different sources of ionizing radiation (without, e.g. contamination upon breakdown in Czarnobyl, X-ray medical diagnostics, radionuclides in soil, radon inside and outside building) in 1997 was $3.08 \mathrm{mSv}$.

\section{Conclusion}

Every day people are exposed to small amounts of ionizing radiation, not only from water sources, but also from radionuclide constituting a natural radiation background which varies according to the environmental conditions. Although radon gets into some homes through water, it is important to first test the air in the home for radon. While deciding whether or not to take steps to reduce the concentration of radon in drinking water supplies, it is important to take account of the contribution of other sources of radon to the total radiation dose. Any action should be both justified and optimized and take account of local conditions.

The problem of radon in Mokre in Głubczyce poviat appeared with the necessity to identify radon in drinking water which was connected with the amendment of the Regulation of the Minister of Health on the quality of water intended for human consumption. However, the achieved results of radon concentration were not surprising because, due to geological structure of this land, this situation could be foreseen. Especially, considering the fact that radon had been removed from water for a few years [2] in nearby Krnov.

Nevertheless, until 30.11.2017, there was no obligation to measure this parameter in Poland. At the same time, evaluating the health threat connected with radon content in water, it is necessary to state that it is insignificant as the calculated annual effective dose equivalent of radiation coming from tap water is very low. It is also necessary to highlight that data on increased lung cancer occurrence in the higher radiation level areas presented in the literature are not unequivocal.

The problem of an influence of low doses of radiation, similar to background levels, is still under debate and this is the reason for studies of the correlation between natural radiation levels and cancer cases. The tests conducted by Polish doctors in 2012 [14] show that the relative risk of cancer deaths is lower in the higher radiation level areas. The decrease by $1.17 \% / \mathrm{mSv} /$ year $(\mathrm{p}=0.02)$ of all cancer deaths and by $0.82 \% / \mathrm{mSv} /$ year $(\mathrm{p}=$ 0.2 ) of lung cancers is only observed. The tests conducted by Sanders also [18] confirm that some doses of ionizing radiation can decrease the number of cancers in the population. Feinendegen et al. [19], Calabrese and Baldwin [20] and Luckey [21] said that the possible radiation hormetic effect is connected with adaptive response of the human immune system which is activated for better protection and repair of DNA damage.

In conclusion, the problem of radon content in drinking water and its release to rooms has always been present in Poland, however, so far, it has not been necessary to conduct detailed analyses. Since the calculations presented in this paper are highly estimated, the next stage of tests was started in Mokre in March 2018 with the use of passive dosimeters. 10 residential facilities were selected for tests in which 4 cassettes - two in the bathroom and two in the rooms without water taps - were placed. The cassettes will be exposed for the period of minimum 3 months and next they will be subject to analyses in the laboratory. At the same time, intensive tests on removal of random from water in the storage tank are conducted. The results of these tests will be presented in the subsequent publications. 


\section{References}

1. Health Risks of Radon. US Environmental Protection Agency. www.epa.gov/radon/health-risk-radon (2017)

2. I. Kłosok-Bazan, E. Sindelarova, M. Gono, Instal 2: 66-69 (2014)

3. S. Lehnert, Biomolecular action of ionizing radiation. Taylor \& Francis; New York London (2007)

4. M. Erdogan, K. Manisa, F. Tel, Carpathian Journal of Earth and Environmental Sciences. 10 (2015)

5. WHO handbook on indoor radon. A public health perspective, WHO http://apps.who.int/iris/bitstream/10665/44149/1/9789241547673 eng.pdf?u (2009)

6. C. R. Cothern, Journal of American Water Works Association, 79, (1987)

7. A. Cucoş, B. Papp, T. Dicu, M. Moldovan, D. B. Burghele, I. T. Moraru, A. Tenţer, C. Cosma, Journal of Environmental Radioactivity 166, 2 ( 2017)

8. M Kreuzer, N Fenske, M Schnelzer, L Walsh, British Journal of Cancer 113 ( 2015)

9. P. Wojtyla-Buciora, J. T. Marcinkowski, Probl Hig Epidemiol 91, 1 (2010)

10. WHO Guidelines for drinking-water quality, 4th edition (2017)

11. Council Directive No 96/29 Euroatom of 13 May 1996 laying down basic safety standards for the protection of the health of workers and the general public against the dangers arising from ionizing radiation

12. H. Synnott, D. Fenton, An evaluation of radon Reference Levels and radon measurement techniques and protocols in European countries. European radon Research and Industry Collaborative Concerted Action (ERRICCA2), European Commission Contract (FIRI-CT-2001-20142), (2005)

\section{https://www.epa.ie/pubs/reports/radiation/RPII_ERRICA_Measure_Report 05.pdf}

13. W. Bobinski et al. Objaśnienia do mapy geośrodowiskowej Polski. Arkusz Pitrowice(964). Panstwowy Istytut Geologiczny (2004)

14. K. W. Formalski, L. Dobrzynski, Dose Response 10, 4(2012)

15. A. Pawula, Koncentracja radonu $w$ budynkach a graniczna dawka promieniowania jonizującego, Sesja Naukowa "Radon w środowisku" Kraków (2000)

16. M. Dohojda, Building Reaserach Institute, Quaterty 1, 129 (2004)

17. J.A Rubin, Architektura i Technika a zdrowie (2003)

18. Sanders CL. Radiation Hormesis and the Linear-No-Threshold Assumption. Springer; Heidelberg (2010)

19. Feinendegen LE, Bond VP, Soudhaus CA. The dual response to low-dose irradiation: induction vs. prevention of DNA damage. In: Yamada T, Mothersill C, Michael BD, Potten CS, editors. Biological Effects of Low Dose Radiation. Elsevier Science;. pp. 317. International Congress Series 1211. Amsterdam: (2000)

20. Calabrese EJ, Baldwin LA.. Human \& Ecological Risk Assessment 8,2 (2002)

21. Luckey TD. Dose-Response. 4, 3 (2006) 